\title{
Studi Kasus Asuhan Keperawatan Psikososial Dengan Masalah Harga Diri Rendah Situsional Pada Penderita Gout Atritis
}

\author{
Inri Sihombing \\ Inrisihombing3006@gmail.com
}

\section{BAB 1 \\ PENDAHULUAN}

\subsection{Latar Belakang}

Gout atau artritis adalah gangguan gerak pada kaki,nyeri,kesulitan berjalan, dan kesulitan dalam melakukan aktivitas sehari-hari yang disebabkan oleh inflamasi karena adanya endapan Kristal asam urat pada rongga sendi. Apabila dibiarkan akan menimbulkan kecacatan, deformitas, stres, dan penurunan kualitas hidupdan menimbulkan komplikasi lebih lanjut serta gangguan ginjal dan jantung bahkan sampai kematian (stewart et al., 2016). Penanganan gout yang dilakukan secara farmakologi diberikan dengan obat yang mempunyai efek ketidaknyamanan perut, dan diare, nefopatik, reaksi alergi dan peningkatan toksisitas 6-mercaptopurine serta hepatitis (Ragab 2017;Hendriani \& Sukandar, 2016).

Penyebab gout yaitu sering mengonsumsi makanan-makanan yang mengandung purin, meminum alcohol, kurang berolahraga, makan terlalu cepat, pengeluaran asam urat yang rendah akan meningkatkan asam urat di dalam darah. Tingkat asam urat yang tidak normal adalah kurang dari 2 $\mathrm{mg} / \mathrm{dL}$ atau lebih dari $7 \mathrm{mg} / \mathrm{dL}$. Untuk laki-laki kurang dari $2 \mathrm{mg} / \mathrm{dL}$ atau lebih dari 6,5 mg/dL untuk perempuan (Ekpenyong \& Daniel, 2015). Akibat dari tingginya kadar asam urat akan menyebabkan rasa sakit yang luar biasa yang dialami pada kaki dang menggaggu aktivitas dalam memenuhi kebutuhan sehari-hari.

Prevalensi kasus Gout arthritis menurut WHO (World Health 
Organization), hiperurisemia terjadi pada 5-30\% populasi umum dan prevalensi dapat lebih tinggi pada beberapa kelompok etnik tertentu. Prevalensi gout belakangan ini menunjukkan peningkatan di seluruh dunia, diduga karena peningkatan prevalensi dan penggunaan obat-obatan. Kejadian gout bervariasi antara 0,16-1,36\%, sedangkan menurut data yang ditemukan oleh Johnstone (2017), prevalensi gout bervariasi dari 0,2\% di Eropa dan Amerika Serikat sampai 10\% pada laki-laki dewasa pada populasi Maori di Selandia Baru (Wisesa dan Suastika, 2017). Di Indonesia diperkirakan 12\%-34\% dari 18,3 juta orang penduduk Indonesia. Prevalensi ini meningkat seiring dengan meningkatnya umur dan cukup bervariasi antara satu daerah dengan daerah yang lain. Dari data yang didapatkan nyeri pada serangan gout banyak di derita pada penduduk Indonesia diatas umur 45 tahun. Seiring dengan meningkatnya jumlah penduduk didunia maka jumlah penderita gout secara otomatis akan meningkat pula (Ahmad, 2016). Prevalensi nasional penyakit sendi adalah 30,3\% (berdasarkan diagnosis tenaga kesehatan dan gejala). Sedangkan prevalensi penyakit Gout arthritis di Jawa Timur adalah 26,4\% (Kemenkes RI, 2016). Menurut profil kesehatan Madiun ditemukan 9.750 kasus tentang penyakit pada system otot termasuk sendi yang banyak dilayani pada Puskesmas (Profil Kesehatan Madiun, 2016). Sedangkan data yang diperoleh dari puskesmas Dagangan tahun 2019 dan hasil pemeriksaan Gout arthritis di Kecamatan Dagangan didapatkan penderita Gout arthritis sebanyak 50 orang berdasarkan data yang periksa. dan hampir seluruhnya mengeluh nyeri sendi yang sangat mengganggu aktivitas.

Masalah harga diri rendah perlu mendapatkan penanganan yang tepat karena jika tidak hal ini dapat menyebabkan timbulnya masalah psikologis lain yang lebih serius. Morton (2016) menyebutkan bahwa masalah harga diri rendah dapat berkembang menjadi gangguan jiwa seperti depresi Ansietas dan panik. Potter, Perry (2019) juga menyebutkan bahwa perilaku individu biasanya sesuai dengan konsep diri dan harga diri yang dimilikinya, individu yang memiliki harga diri yang rendah sering kali tidak dapat mengontrol 
situasi dan tidak merasakan manfaat dari pelayanan yang akan mempengaruhi keputusan tentang pelayanan kesehatan. Oleh karena itu perawat perlu memberikan perhatian yang serius dalam mengatasi masalah harga diri rendah situasional yang dialami penderita Gout Artritis. Hal ini tidak hanya bertujuan untuk mengatasi masalah psikologis itu sendiri tapi juga diharapkan dapat mencegah terjadinya masalah kesehatan lain yang lebih serius.

Penderita Gout artritis selain dapat mengalami masalah psikososial berupa HDR situasional akibat kondisi kesehatannya yang menurun juga dapat mengalami masalah ansietas atau kecemasan. Hal ini sebagaimana disebutkan dalam Stuart (2018) Harga diri yang tinggi dikaitkan dengan kecemasan yang rendah, efektif dalam kelompok dan penerimaan orang lain terhadap dirinya, sedangkan masalah kesehatan dapat menyebabkan harga diri, sehingga harga diri dikaitkan dengan hubungan interperonal yang buruk dan beresiko terjadinya depresisehingga perasaan negatif mendasari hilangnya kepercayaan diri dan harga diri individu dan menggambarkan gangguan harga diri (Pardede, Hutajulu, Pasaribu, 2020) Seorang penderita Gout artritis yang mengalami HDR situasional juga memiliki kemungkinan mengalami kecemasan akibat merasakan ketidaknyamanan, kekhawatiran atau ketakutan terkait kondisi kesehatannya. Kondisi kecemasan yang dialami dapat membuat penderita menjadi tidak fokus dan kurang mampu berpikir positif dan realistis. Oleh karena itu pendekatan asuhan keperawatan pada penderita Gout artritis perlu dilakukan secara holistik untuk menciptakan pelayanan yang lebih berkualitas. Hal ini juga diharapkan dapat membantu meningkatkan kepuasan klien terhadap pelayanan keperawatan dan diharapkan dapat memberi kontribusi yang positif terhadap pengendalian penyakit Potter, Perry (2019).

Survei awal yang dilakukan di Sidorame Timur maka ditemukan pasien mengalami perubahan pada perilakunya seperti menunduk, menghindari kontak mata dan memiliki kesan tertutup ketika diajak 
komunikasi dengan harga diri rendah situasional akibat penyakit

Gout artritis yang bernama Ny.E di Sidorame Timur.

\subsection{Rumusan Masalah}

Berdasarkan masalah yang telah di paparkan pada latar belakang maka rumusan masalah dalam askep ini yaitu Asuhan Keperawatan Ny. E dengan Harga Diri Rendah Situasional Di Sidorame Timur.

\subsection{Tujuan}

\subsubsection{Tujuan Umum}

Mahasiswa mampu memberikan asuhan keperawatan secara holistik dan komprehensif kepada Ny. E dengan Harga Diri Rendah Di Sidorame Timur

\subsubsection{Tujuan Khusus}

a. Mahasiswa mampu memahami pengertian, tanda dan gejala, etiologi, penatalaksanaan medis dan keperawatan Harga Diri Rendah.

b. Mahasiswa mampu melakukan pengkajian pada Ny. E dengan gangguan Harga Diri Rendah

c. Mahasiswa mampu melakukan menegakkan diagnosa pada Ny. E dengan gangguan Harga Diri Rendah

d. Mahasiswa mampu melakukan menetapkan perencanaan pada $\mathrm{Ny}$. E dengan gangguan Harga Diri Rendah.

e. Mahasiswa mampu melakukan implementasi pada Ny. E dengan gangguan Harga Diri Rendah.

f. Mahasiswa mampu melakukan evaluasi pada Ny. E dengan gangguan Harga Diri Rendah.

g. Mendokumentasikan asuhan keperawatan yang diberikan pada $\mathrm{Ny}$. E dengan gangguan Harga Diri Rendah. 


\section{BAB 2}

\section{TINJAUAN TEORITIS}

\subsection{Konsep Artritis Gout}

\subsubsection{Definisi}

Penyakit arthritis gout merupakan salah satu jenis rematik. Apabila dibagi menurut jenisnya, rematik dibedakan menjadi dua, yaitu rematik sendi dan rematik nonsendi. Penyakit arthritis gout adalah salah satu jenis rematik nonsendi. Arthritis gout disebabkan oleh tingginya kadar asam urat dalam darah yang kemudian asam urat tersebut tidak bisa diekskresikan melalui urin sehingga menumpuk di persendian (Soeryoko, 2016).

Asam urat diproduksi sendiri oleh tubuh sehingga keberadaannya normal ada di dalam darah. Asam urat terbentuk sebagai sisa metabolisme protein makanan yang mengandung purin. Oleh karena itu, kadar asam urat di dalam darah akan meningkat apabila seseorang banyak mengonsumsi daging atau makanan lainnya yang mengandung purin tinggi. Zat purin yang diproduksi oleh tubuh jumlahnya mencapai 85\%. Untuk mencapai $100 \%$ tubuh manusia hanya memerlukan asupan purin dari luar tubuh (makanan) sebesar 15\%. Ketika asupan purin dari makanan yang masuk ke dalam tubuh melebihi 15\%, akan terjadi penumpukan zat purin (Noviyanti, 2015).

\subsubsection{Penyebab Artritis Gout}

Menurut Naga (2016), penyakit gout dibagi menjadi dua, yaitu gout primer dan gout sekunder.

1) Gout primer adalah gout yang disebabkan oleh faktor genetik. Kombinasi faktor genetik dan hormonal diduga menjadi penyebab terganggunya metabolisme. Akibatnya, produksi asam urat juga ikut 
meningkat. Gout jenis ini juga dapat diakibatkan karena berkurangnya pengeluaran asam urat dari tubuh. Namun pada penyakit gout primer ini, $99 \%$ penyebabnya belum diketahui (idiopatik).

2) Gout sekunder biasanya timbul karena adanya komplikasi dengan penyakit lain (hipertensi). Penyebab lain gout sekunder antara lain karena meningkatnya produksi asam urat akibat nutrisi, yaitu mengonsumsi makanan dengan kadar purin tinggi.

\subsubsection{Tanda dan Gejala}

Menurut Soekanto (2017), tanda dan gejala yang biasa dialami oleh penderita penyakit arthritis gout adalah:

1) Kesemutan dan linu.

2) Nyeri terutama pada malam atau pagi hari saat bangun tidur. Sendi yang terkena arthritis gout terlihat bengkak, kemerahan, panas, dan nyeri luar biasa.

\subsubsection{Komplikasi}

Komplikasi dari arthritis gout belum banyak disadari oleh masyarakat umum. Menurut Soeryoko (2011), berikut ini komplikasi yang terjadi akibat tingginya kadar asam urat.

1) Kerusakan sendi

2) Terbentuk tofi

3) Penyakit Jantung

4) Batu Ginjal

5) Batu Ginjal (nefopatik gout) 


\subsubsection{Penatalaksanaan}

Penatalaksanaan ditujukan untuk mengakhiri serangan akut secepat mungkin, mencegah serangan berulang dan pencegahan komplikasi. Menurut Junaidi (2016), penatalaksanaan yang bisa dilakukan adalah:

1) Medikasi

a) Pengobatan serangan akut dengan Colchine 0,6 mg PO, Colchine 1,0 - 3,0 mg (dalam Nacl/IV), phenilbutazon, Indomethacin.

b) Terapi farmakologi (analgetik dan antipiretik)

c) Colchines (oral/iv) tiap 8 jam sekali untuk mencegah fagositosis dari kristal asam urat oleh netrofil sampai nyeri berkurang.

d) Nostreoid, obat - obatan anti inflamasi (NSAID) untuk nyeri dan inflamasi.

e) Allopurinol untuk menekan atau mengontrol tingkat asam urat dan untuk mencegah serangan.

f) Uricosuric untuk meningkatkan eksresi asam urat dan menghambat akumulasi asam urat.

g) Terapi pencegahan dengan meningkatkan eksresi asam urat menggunakan probenezid 0,5 g/hari atau sulfinpyrazone (Anturane) pada pasien yang tidak tahan terhadap benemid atau menurunkan pembentukan asam urat dengan Allopurinol $100 \mathrm{mg}$ 2x/hari.

2) Perawatan

a) Anjurkan pembatasan asupan purin : Hindari makanan yang mengandung purin yaitu jeroan (jantung, hati, lidah, ginjal, usus), 
sarden, kerang, ikan herring, kacang - kacangan, bayam, udang, dan daun melinjo.

b) Anjurkan asupan kalori sesuai kebutuhan : Jumlah asupan kalori harus benar disesuaikan dengan kebutuhan tubuh berdasarkan pada tinggi dan berat badan.

c) Anjurkan asupan tinggi karbohidrat kompleks seperti nasi, singkong, roti dan ubi sangat baik di konsumsi oleh penderita gangguan asam urat karena akan meningkatkan pengeluaran asam urat melalui urin.

d) Anjurkan asupan rendah protein, rendah lemak.

e) Anjurkan pasien untuk banyak minum air putih. Hindari penggunaan alkohol.

\subsection{Konsep Harga Diri Rendah Situsional}

\subsubsection{Definisi}

Harga diri rendah adalah evaluasi diri yang negatif, berupa mengkritik diri sendiri, dimana seseorang memiliki fikiran negatif dan percaya bahwa mereka ditakdirkan untuk gagal (Rahayu, Mustikasari \& Daulima, 2019). Harga diri rendah merupakan perasaan negatif terhadap dirinya sendiri, termasuk kehilangan kepercayaan diri, tidak berharga, tidak berguna, pesimis, tidak ada harapan dan putus asa (Purwasih \& Susilowati, 2016).

Harga diri rendah merupakan keadaan dimana individu mengalami evaluasi diri negatif tentang kemampuan dirinya Sehingga dapat diambil kesimpulan bahwa harga diri rendah yaitu dimana individu mengalami gangguan dalam penilaian terhadap dirinya sendiri dan kemampuan yang dimiliki, yang menjadikan hilangnya rasa kepercayaan diri akibat evaluasi 
negatif yang berlangsung dalam waktu yang lama karena merasa gagal dalam mencapai keinginan (Febrina, 2018).

\subsubsection{Faktor Penyebab Harga Diri Rendah Situsional}

Faktor yang mempengaruhi harga diri rendah kronis meliputi faktor Predisposisi dan faktor Presipitasi yaitu (Diana, 2020) :

\section{Faktor Predisposisi}

a. Faktor yang mempengaruhi harga diri rendah meliputi penolakan dari orang tua, seperti tidak dikasih pujian, dan sikap orang tua yang terlalu mengekang, sehingga anak menjadi frustasi dan merasa tidak berguna lagi serta merasa rendah diri.

b. Faktor yang mempengaruhi harga diri rendah juga meliputi ideal diri seperti dituntut untuk selalu berhasil dantidak boleh berbuat salah, sehingga anak kehilangan rasa percaya diri.

\section{Faktor Presipitasi}

Faktor presipitasi ditimbulkan dari sumber internal dan eksternal misalnya ada salah satu anggota yang mengalami gangguan mental sehingga keluarga merasa malu dan rendah diri. Pengalaman traumatik juga dapat menimbulkan harga diri rendah seperti penganiayaan seksual, kecelakaan yang menyebabkan seseorang dirawat di rumah sakit dengan pemasangan alat bantu yang tidak nyaman baginya. Respon terhadap trauma umumnya akan mengubah arti trauma dan kopingnya menjadi represi dan denial.

\subsubsection{Tanda dan Gejala Harga Diri Rendah Situsional}

Manifestasi yang biasanya muncul pada klien skizofrenia dengan masalah harga diri rendah kronis, menurut Rahmawati (2019) :

1. Data Subjektif

a. Pasien mengungkapkan hal negatif terhadap diri sendiri dan orang lain. 
b. Pasien mengungkapkan perasaan tidak mampu.

c. Pasien mengungkapkan pandangan hidup yang pesimis.

d. Pasien mengungkapkan penolakan terhadap kemampuan diri.

e. Pasien mengungkapkan evaluasi diri tidak mampu mengatasi situasi.

\section{Data Objektif}

a. Adanya penurunan produktivitas.

b. Pasien cenderung tidak berani menatap lawan bicaranya.

c. Pasien lebih banyak menundukkan kepala saat berinteraksi dengan orang lain.

d. Berbicara lambat dengan nada suara lemah.

e. Bimbang, menunjukkan perilaku non-asertif.

f. Mengekspresikan diri tidak berdaya dan tidak berguna.

\subsubsection{Proses Terjadinya Harga Rendah Diri Rendah Situsional}

Proses Terjadinya Harga Diri Rendah Harga diri rendah kronis merupakan lanjutan dari gangguan pada diri klien yang terjadi akibat harga diri rendah situasional yang tidak terselesaikan atau ketidakadaan feed back (umpan balik) yang positif dari lingkungan terhadap perilaku klien sebelumnya. Respon negatif dari lingkungan juga memiliki peran terhadap gangguan harga diri rendah kronis.Pada awalnya klien dihadapkan dengan stresor (krisis) dan berusaha untuk menyelesaikannya tetapi tidak tuntas. Ketidaktuntasan itu menimbulkan evaluasi diri bahwa ia tidak mampu atau gagal menjalankan peran dan fungsinya. Evaluasi diri yang negatif karena merasa gagal merupakan gangguan harga diri rendah situasional yang berlanjut menjadi harga diri rendah kronis akibat tidak adanya respon positif dari lingkungan pada klien (Safitri, 2020). 


\subsubsection{Rentang Respon Harga Diri Rendah Kronis}

Adapun rentang respon harga diri rendah kronis menurut (Dwi, 2020)

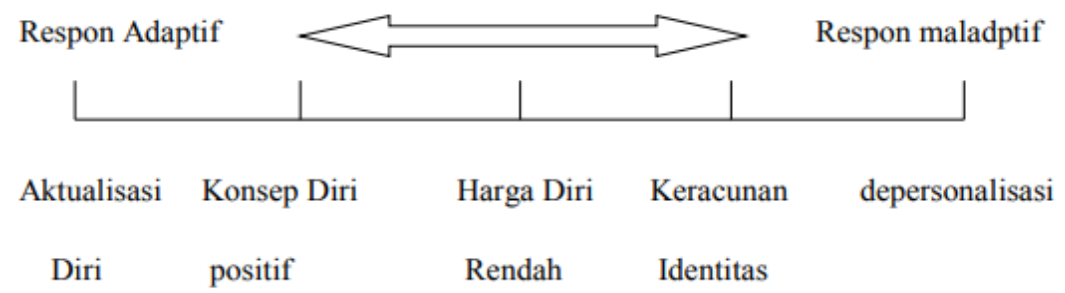

\section{Keterangan :}

1. Aktualisasi diri : Pernyataan konsep diri positif dengan pengalaman sukses.

2. Konsep diri positif : Mempunyai pengalaman positif dalam perwujudan dirinya.

3. Harga diri rendah : Perasaan yang negatif pada diri sendiri, hilangnya percaya diri, tidak berharga lagi, tidak berdaya, dan pesimis.

4. Keracunan identitas : Kegagalan seseorang untuk mengintegrasikan berbagai identifikasi masa anak-anak.

5. Dipersonalisasi : Perasaan sulit membedakan diri sendiri dan merasa tidak nyata dan asing

\subsubsection{Mekanisme Koping Harga Diri Rendah}

Seseorang dengan harga diri rendah kronis memiliki mekanisme koping jangka pendek dan jangka panjang. Jika mekanisme koping jangka pendek tidak memberikan hasil yang telah diharapkan individu, maka individu dapat mengembangkan mekanis koping jangka panjang (Dwi, 2020).

Mekanisme tersebut mencakup sebagai berikut :

1. Jangka Pendek 
a. Aktivitas yang dilakukan untuk pelarian sementara yaitu : pemakaian obat-obatan, kerja keras, nonton tv secara terus menerus.

b. Aktivitas yang memberikan penggantian identitas bersifat sementara, misalnya ikut kelompok sosial, agama, dan politik).

c. Aktivitas yang memberikan dukungan bersifat sementara misalnya perlombaan.

\section{Jangka Panjang}

Penutupan identitas :

a. terlalu terburu-buru mengadopsi identitas yang disukai dari orang-orang yang berarti tanpa memperhatikan keinginan atau potensi diri sendiri.

b. Identitas Negatif : asumsi identitas yang bertentangan dengan nilai-nilai dan harapan masyarakat.

\subsection{Konsep Asuhan Keperawatan Jiwa}

\subsubsection{Pengkajian keperawatan}

Pengkajian merupakan pengambilan data yang dilakukan pertama kali oleh perawat setelah pasien masuk. Pengkajian merupakan tahap awal dari proses keperawatan. Disini semua data dikumpulkan secara sistematis untuk menentukan status kesehatan klien saat ini. Pengkajian harus dilakukan secara komprehensif terkait dengan aspek biologis, psikologis, social maupun spiritual klien. Pengkajian keperawatan tidak sama dengan pengkajian medis. Pengkajian medis difokuskan pada keadaan patologis, sedangkan pengkajian keperawatan ditujukan pada respon klien terhadap masalah-masalah kesehatan yang berhubungan dengan pemenuhan kebutuhan dasar manusia. Misalnya dapatkah klien melakukan aktivitas sehari-hari, sehingga fokus pengkajian klien adalah 
respon klien yang nyata maupun potensial terhadap masalah-masalah aktifitas harian (Sitorus, 2019).

\subsubsection{Diagnosa Keperawatan}

1) Artritis gout

2) Kecemasan

3) Isolasi Sosial

4) Harga Diri rendah Situsional

\subsubsection{Tindakan Keperawatan}

Implementasi disesuaikan dengan rencana tindakan keperawatan. Pada situasi nyata sering pelaksanaan jauh berbeda dengan rencana, hal ini terjadi karena perawat belum terbiasa menggunakan rencana tertulis dalam melaksanakan tindakan keperawatan. Sebelum melaksanakan tindakan keperawatan yang sudah direncanakan, perawat perlu memvalidasi dengan singkat apakah rencana tindakan masih sesuai dan dibutuhkan pasien sesuai dengan kondisinya (here and now). Perawat juga menilai diri sendiri, apakah kemampuan interpersonal, intelektual, tekhnikal sesuai dengan tindakan yang akan dilaksanakan, dinilai kembali apakah aman bagi pasien. Setelah semuanya tidak ada hambatan maka tindakan keperawatan boleh dilaksanakan (Rokhimma \& Rahayu, 2020).

\subsubsection{Evaluasi Keperawatan}

Evaluasi adalah proses yang berkelanjutan untuk menilai efek dari tindakan keperawatan pada klien. Evaluasi dilakukan terus menerus pada respon klien terhadap tindakan yang telah dilaksanakan, evaluasi dapat dibagi dua jenis yaitu: evaluasi proses atau formatif dilakukan selesai melaksanakan tindakan. Evaluasi hasil atau sumatif dilakukan dengan membandingkan respon klien pada tujuan umum dan tujuan khusus yang telah ditentukan. Evaluasi keperawatan yang diharapkan 
pada pasien yang mendapatkan asuhan keperawatan halusinasi, pasien mampu mengenali halusinasi, klien terlatih mengontrol halusinasi, klien mampu bercakap-cakap dengan orang lain, klien mampu beraktivitas secara terjadwal (Andri, 2019). 


\section{BAB 3}

\section{TINJAUAN KASUS}

\subsection{Pengkajian Keperawatan}

\begin{tabular}{|l|l|}
\hline Nama : Ny .E & Kondisi saat MRS: \\
Usia : 58 tahun & Kondisi saat ini : \\
Tahun no reg : - & Kondisi pasien saat ini secara fisik mengalami gangguan pernafasan, dan \\
Ruangan : - & memiliki riwayat maag dan cenderung mengelak ketika ditanya orang lain \\
Tgl masuk rs: - & mengenai penyakitnya. Dan merasa takut dengan pengobatan yang akan di \\
Tgl pengkajian : 6 oktober 2021 & lakukan selanjutnya. \\
Alamat : Jl Sidorame Timur &
\end{tabular}

\subsubsection{Faktor Predisposisi Dan Faktor Presipitasi}

\begin{tabular}{|c|c|c|c|c|}
\hline \multirow[t]{2}{*}{ Faktor predisposisi } & \multicolumn{3}{|l|}{ Faktor presipitasi } & \multirow[t]{2}{*}{ STRESSOR } \\
\hline & Nature & Origin & $\begin{array}{l}\text { Number \& } \\
\text { Timing }\end{array}$ & \\
\hline $\begin{array}{l}\text { Biologis: } \\
\begin{array}{l}\text { 1. Gout Artritis } \\
\text { 2. Ny. E mengalami Gout Artritis } 3 \text { bulan yang } \\
\text { lalu } \\
\text { 3. Pasien memiliki riwayat penyakit maag }\end{array}\end{array}$ & $\begin{array}{l}\text { - Badan lemas, } \\
\text { Batuk }\end{array}$ & Internal & $\begin{array}{l}\text { Sejak } 3 \\
\text { bulan yang } \\
\text { lalu }\end{array}$ & - Gout Artritis \\
\hline
\end{tabular}




\begin{tabular}{|c|c|c|c|c|}
\hline $\begin{array}{l}\text { 4. Ttv : } \\
\begin{array}{l}\text { Td }: 110 / 80 \mathrm{mmHg} \\
\mathrm{N}: 88 \mathrm{x} / \mathrm{i} \\
\mathrm{S}: 37 \mathrm{C} \\
\mathrm{RR}: 22 \mathrm{x} / \mathrm{i}\end{array}\end{array}$ & & & & \\
\hline $\begin{array}{l}\text { Psikologis : } \\
\text { 1. Ny. E merasa malu karena penyakitnya dan } \\
\text { khawatir akan masa depannya } \\
\text { 2. Ny. E cenderung mengelak ketika ditanya } \\
\text { penyakitnya } \\
\text { 3. Ny. E memiliki kepribadian terbuka tetapi } \\
\text { ketika sakit menjadi malu untuk bertemu } \\
\text { orang lain. } \\
\text { 4. Ny. E juga merasa cemas akan pengobatan } \\
\text { OAT yang menurutnya makin memperburuk } \\
\text { kondisinya. }\end{array}$ & $\begin{array}{l}\text { - } \text { Merasa malu } \\
\text { karena penyakitnya } \\
\text { - Malu karena } \\
\text { berhenti bekerja } \\
\text { - Cemas akan } \\
\text { pengobatan } \\
\text { selanjutnya }\end{array}$ & Internal & Saat ini & $\begin{array}{l}\text { - Malu, Cemas, } \\
\text { takut panik, } \\
\text { kwatir }\end{array}$ \\
\hline $\begin{array}{l}\text { Sosiocultural : } \\
\text { 1. Ny. E seorang perempuan umur } 22 \text { tahun } \\
\text { 2. Ny. E sudah menikah } \\
\text { 3. Sebelumnya Nn.E bekerja sebagai PRT, dan }\end{array}$ & $\begin{array}{l}\text { Kebutuhan hidup di } \\
\text { penuhi sendiri }\end{array}$ & Ekternal & Saat ini & $\begin{array}{ll}\text { Harga } & \text { Diri } \\
\text { Rendah } & \\
\text { Situasional } & \end{array}$ \\
\hline
\end{tabular}




\begin{tabular}{|l|l|l|l|}
\hline $\begin{array}{l}\text { berhenti bekerja karena penyakitnya } \\
\text { 4. Ny.E merupakan orang batak dan menurut } \\
\text { Nn.E tidak ada kebiasaan yang bertentangan } \\
\text { dengan kesehatan } \\
\text { 5. Ny.E beragama kristen dan taat menjalankan } \\
\text { ibadah }\end{array}$ & & & \\
\hline GENOGRAM & $\begin{array}{l}\text { Ny.E Tinggal dengan suami dan } \\
\text { empat orang anaknya. Dua laki- } \\
\text { laki, dan dua perempuan. }\end{array}$ \\
\hline
\end{tabular}

Ket

Laki-Laki Pasien Pasien 


Perempuan
$\bigotimes$ Meninggal Dunia
Tinggal Bersama Keluarga

3.1.2 Penilaian (Respon)Terhadap Stressor

\begin{tabular}{|c|c|c|c|c|c|c|}
\hline STRESSOR & KOGNITIF & AFEKTIF & FISIOLOGIS & PERILAKU & SOSIAL & $\begin{array}{c}\text { DIAGNOSA } \\
\text { KEPERAWATAN }\end{array}$ \\
\hline $\begin{array}{l}\text { BIOLOGIS } \\
\text { - Gout } \\
\text { Artritis }\end{array}$ & 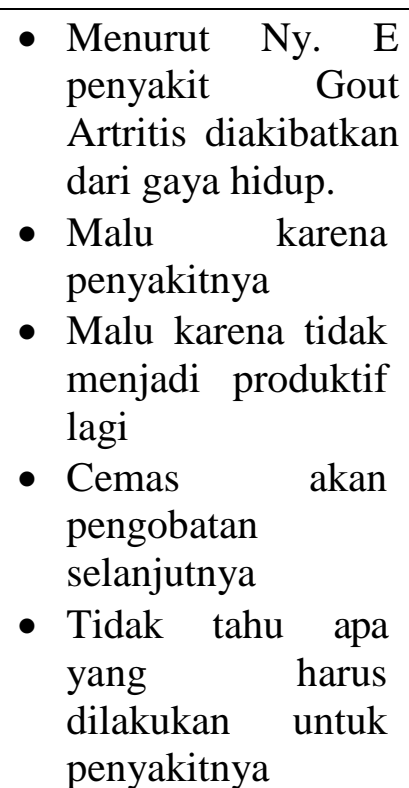 & $\begin{array}{ll}\text { - } & \text { Ny.E } \\
\text { merasa } \\
\text { malu dan } \\
\text { cemas } \\
\text { kondisi } \\
\text { penyakitn } \\
\text { ya }\end{array}$ & $\begin{array}{l}\text { - Sedih } \\
\text { - Pusing } \\
\text { - Malu } \\
\text { - Takut } \\
\text { - Merasa tidak } \\
\quad \text { berguna } \\
\text { - tampak lemas } \\
\text { - Pemeriksaan } \\
\quad \text { TTV } \\
\text { TD: } 110 / 80 \\
\text { mmhg } \\
\mathrm{N}: 88 \times \text { x /menit } \\
\mathrm{P}: 22 \mathrm{x} / \text { menit } \\
\mathrm{S}: 37{ }^{0} \mathrm{C}\end{array}$ & 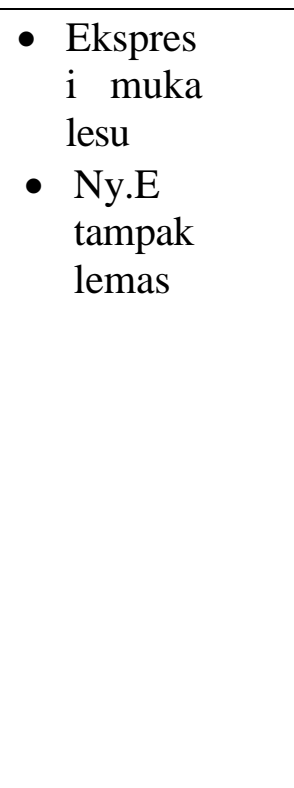 & 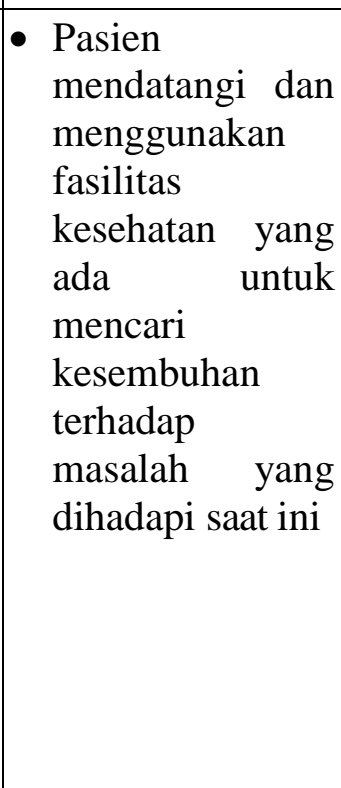 & - Gout Artritis \\
\hline
\end{tabular}




\begin{tabular}{|c|c|c|c|c|c|c|}
\hline $\begin{array}{l}\text { PSIKOLOGIS } \\
\text { - Sedih } \\
\text { - Malu } \\
\text { - Takut } \\
\text { - Merasa } \\
\text { tidak } \\
\text { berguna } \\
\text { - tampak } \\
\text { lemas }\end{array}$ & $\begin{array}{l}\text { - Malu karena } \\
\text { penyakitnya } \\
\text { - Malu karena tidak } \\
\text { menjadi produktif } \\
\text { lagi Cemas akan } \\
\text { pengobatan } \\
\text { selanjutnya } \\
\text { - Mengaku bingung } \\
\text { mengenai } \\
\text { penyakitnya }\end{array}$ & $\begin{array}{l}-{ }^{-} \text {merasa malu } \\
\text { dan cemas } \\
\text { kondisi } \\
\text { penyakitnya }\end{array}$ & $\begin{array}{l}\text { - Sedih } \\
\text { - Malu akan } \\
\text { penyakitnya } \\
\text { - Takut orang } \\
\text { lain mengetahui } \\
\text { penyakitnya } \\
\text { - Merasa tidak } \\
\text { berguna }\end{array}$ & $\begin{array}{l}\text { - } \text { Tampak } \\
\text { cemas } \\
\text { - Kadang } \\
\text { Ny.E } \\
\text { tampak } \\
\text { murung } \\
\text { - Ny.E } \\
\text { menunduk } \\
\text { saat } \\
\text { bercerita }\end{array}$ & $\begin{array}{l}\text { - Hubungan } \\
\text { Ny. E dengan } \\
\text { keluarga baik }\end{array}$ & $\begin{array}{l}\text { - Harga Diri } \\
\begin{array}{l}\text { Rendah } \\
\text { Situasional }\end{array} \\
\text { - Ansietas } \\
\text { - Kurang } \\
\text { Pengatahuan }\end{array}$ \\
\hline \begin{tabular}{l}
\multicolumn{1}{c}{ SOSIAL } \\
BUDAYA \\
- sering \\
Memikirkan \\
tanggapan \\
orang lain \\
terhadap \\
penyakitnya.
\end{tabular} & $\begin{array}{l}\text { - Ny.E merasa malu } \\
\text { dengan } \\
\text { keadaannya } \\
\text { sekarang yang } \\
\text { tidak bisa bekerja } \\
\text { nomor satu. }\end{array}$ & $\begin{array}{l}\text { - Merasa malu } \\
\text { dan khawatir } \\
\text { dan merasa } \\
\text { selalu } \\
\text { mereptan } \\
\text { keluarganya } \\
\text { - Merasa } \\
\quad \text { bosan } \\
\text { dengan } \\
\text { keadaan } \\
\text { sekarang }\end{array}$ & $\begin{array}{l}\text { - Sedih } \\
\text { - Malu } \\
\text { - Takut } \\
\text { - Merasa tidak } \\
\text { berguna } \\
\text { - Ny.E tampak } \\
\text { lemas }\end{array}$ & $\begin{array}{l}\text { - Kontak } \\
\text { mata ada } \\
\text { tapi tidak } \\
\text { bertahan } \\
\text { lama } \\
\text { - Ny.E } \\
\text { terkadang } \\
\text { selalu } \\
\text { menunduk } \\
\text { saat } \\
\text { bercerita } \\
\text { - Volume }\end{array}$ & $\begin{array}{l}\text { - Hubungan } \\
\text { Ny.E dengan } \\
\text { keluarga } \\
\text { Baik } \\
\text { - Hubungan } \\
\text { Ny.E dengan } \\
\text { petugas } \\
\text { kesehatan } \\
\text { baik tetap } \\
\text { - Ny.E tenikuti } \\
\text { mengik } \\
\text { program }\end{array}$ & $\begin{array}{l}\text { Harga Diri } \\
\text { Rendah } \\
\text { Situasional }\end{array}$ \\
\hline
\end{tabular}




\begin{tabular}{|l|l|l|l|l|l|}
\hline & & & & suara & \multicolumn{1}{c|}{$\begin{array}{l}\text { pengobatan } \\
\text { tetapi merasa } \\
\text { takut }\end{array}$} \\
& & & & & \\
\hline
\end{tabular}

Pohon Masalah

Harga diri rendah situasional

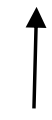

Ansietas

$\varlimsup_{\text {Gout Artritis }}$ 


\subsubsection{Sumber Koping}

\begin{tabular}{|c|c|c|c|c|c|}
\hline $\begin{array}{c}\text { DIAGNOSA } \\
\text { KEPERAWA } \\
\text { TAN }\end{array}$ & PERSONAL ABILITY & $\begin{array}{c}\text { SOSIAL } \\
\text { SUPPORT }\end{array}$ & $\begin{array}{c}\text { MATERIAL } \\
\text { ASSETS }\end{array}$ & $\begin{array}{l}\text { POSITIE } \\
\text { BELIEFS }\end{array}$ & TERAPI \\
\hline $\begin{array}{l}\text { Harga Diri } \\
\text { Rendah } \\
\text { Situasional }\end{array}$ & $\begin{array}{l}\text { - Ketika klien merasa malu } \\
\text { dan bersalah kepada diri } \\
\text { sendiri dan orang lain, } \\
\text { klien berusaha untuk } \\
\text { melakukan kegiatan kecil } \\
\text { untuk mengatasinya, } \\
\text { dengan cara beribadah }\end{array}$ & $\begin{array}{c}\text { Keluarga klien } \\
\text { berperan } \\
\text { penting } \\
\text { terhadap } \\
\text { keadaan pasien }\end{array}$ & $\begin{array}{c}\text { Ketika klien } \\
\text { berobat } \\
\text { kerumah } \\
\text { sakit } \\
\text { menggunaka } \\
\text { n BPJS }\end{array}$ & $\begin{array}{c}\text { Klien } \\
\text { sholat } \\
\text { ketika } \\
\text { diingatkan } \\
\text { oleh } \\
\text { anaknya } \\
\text { karena } \\
\text { sering } \\
\text { lupa } \\
\text { waktu }\end{array}$ & $\begin{array}{ll}\text { 1. } & \text { Terapi } \\
& \text { supportif } \\
\text { 2. } & \text { Kognitif terapi } \\
\text { 3. } & \text { Family } \\
& \text { psikoedukasi }\end{array}$ \\
\hline
\end{tabular}




\begin{tabular}{|c|c|c|c|c|c|}
\hline Ansietas & $\begin{array}{l}\text { - Ny.E mampu mengungkapkan } \\
\text { perasaan cemas } \\
\text { - Ny.E mengatakan bila } \\
\text { cemasnya memuncak maka ia } \\
\text { akan melakukan hal yang } \\
\text { membuat nya sibuk dan lupa } \\
\text { oleh cemasnya }\end{array}$ & $\begin{array}{l}\text { - } \mathrm{Ny.E} \\
\text { mendapat } \\
\text { dukungan dari } \\
\text { keluarga untuk } \\
\text { kesembuhanny } \\
\text { a }\end{array}$ & 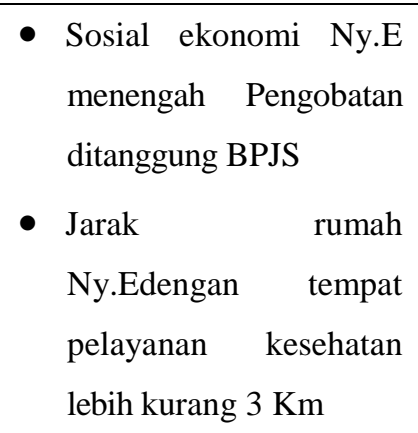 & $\begin{array}{l}\text { - } \text { Ny.E percaya bahwa } \\
\text { petugas kesehatan } \\
\text { akan membantunya } \\
\text { - Ny.E berharap cepat } \\
\text { sembuh agar tidak } \\
\text { merepotkan } \\
\text { Keluarganya }\end{array}$ & $\begin{array}{ll}\text { Terapi spesialis: } \\
\text { - } & \text { Relaksasi } \\
& \text { progresif } \\
\text { - } & \text { Distraksi } \\
\text { - } & \text { Hipnotis } 5 \text { Jari }\end{array}$ \\
\hline $\begin{array}{l}\text { Kurang } \\
\text { Pengetahuan }\end{array}$ & $\begin{array}{l}\text { - Ny.E mampu mengenal } \\
\text { dan menilai keadaan } \\
\text { dari penyakitnya } \\
\text { - Ny.E mampu melatih cara } \\
\text { hidup sehat }\end{array}$ & $\begin{array}{l}\text { - Ny.E } \\
\text { mendapat } \\
\text { dukungan } \\
\text { dari keluarga } \\
\text { untuk } \\
\text { kesembuhan } \\
\text { nya } \\
\text { - keluarga Ny.E } \\
\text { bergantian } \\
\text { menjaga }\end{array}$ & $\begin{array}{l}\text { - Sosial ekonomi Ny.E } \\
\text { menengah Pengobatan } \\
\text { ditanggung BPJS } \\
\text { - Jarak rumah Ny.E } \\
\text { dengan tempat } \\
\text { pelayanan kesehatan } \\
\text { lebih kurang } 3 \mathrm{Km}\end{array}$ & $\begin{array}{l}\text { - Ny.E percaya bahwa } \\
\text { petugas kesehatan } \\
\text { akan membantunya } \\
\text { - Ny.E berharap cepat } \\
\text { sembuh agar tidak } \\
\text { merepotkan } \\
\text { Keluarganya }\end{array}$ & $\begin{array}{l}\text { Terapi } \\
\text { generalis: } \\
\text { - SP 1-2 } \\
\text { kurang } \\
\text { pengetahua } \\
\text { n } \\
\text { - Terapi } \\
\text { spesialis: } \\
\text { Terapi suportif, } \\
\text { FPE }\end{array}$ \\
\hline
\end{tabular}




\subsubsection{Mekanisme Koping}

\section{HAL YANG \\ DILAKUKAN}

ANALISA

- Ny.E mengatakan bila ada masalah, maka ia akan membicarakan

\section{- Konstruktif:} dengan suami dan keluarga untuk mencari jalan keluarnya

- Bila sakit Ny. E berobat ke pelayanan kesehatan

- Ny.E taat menjalankan ibadah sesuai dengan keyakinannya

- Ny.E selalu berdoa kepada Allah SWT untuk kesembuhannya

$\checkmark$ Ny. E mengatakan bila ada masalah, maka ia akan membicarakan dengan suami dan keluarga untuk mencari jalan keluarnya

$\checkmark$ Bila sakit Ny. E berobat ke pelayanan kesehatan

$\checkmark$ Ny. E taat menjalankan ibadah sesuai dengan keyakinannya

$\checkmark$ Ny. E selalu berdoa kepada Allah SWT untuk kesembuhannya.

- Destruktif : - 


\subsubsection{Status Mental}



Kesimpulan : Mental Status Examination (MSE) tidak ada masalah gangguan jiwa, gangguan Ny. E lebih kepada Gangguan Mental Emosional (GME/Psikososial) 


\subsection{Diagnosa Dan Terapi}

\begin{tabular}{|l|l|}
\hline DIAGNOSA KEPERAWATAN DAN TERAPI KEPERAWATAN & DIAGNOSA MEDIS \\
\hline 1. Harga Diri Rendah Situsional & Gout Artritis \\
Sp2 : Klien dapat mengidentifisi aspek positif dan kemampuan yang dimiliki & \\
Sp3 : Menetapkan atau memilih kegiatan sesuai kemampuan & \\
Sp4 : Melatih kegiatan sesuai kemampuan yang dipilih & \\
2. Ansietas & \\
Sp1: mendiskusikan penyebab,terjadinya prosesterjadi, tanda gejala,akibat & \\
Sp2 :melatih teknik releksasi fisik & \\
Sp3:melatih mengatasi ansietas dengan distraksi dan hipnotis lima & \\
Sp4 : melatih mengatasi ansietas memalui kegiatan spiritual & \\
3. Kurang pengetahuan & \\
Terapi suportif, FPE & \\
\hline
\end{tabular}

\subsection{Implementasi Tindakan Kperawatan Dan Evaluasi}

\begin{tabular}{|l|l|}
\hline IMPLEMENTASI TINDAKAN KPERAWATAN & EVALUASI \\
\hline Tanggal : 06 Oktober 2021 & $\mathbf{S}:$ Bersemangat \\
\hline
\end{tabular}


Jam : $14.00-16.00 \mathrm{wib}$

1. Menenangkan pasien

2. Memahami keadaan pasien

3. Mendiskusikan penyebab,terjadinya prosest terjadi, tanda gejala,akibat

4. Mengidentifikasi aspek positif yang dimiliki pasien yaitu berdoa dan bersyukur.

5. Menilai kemampuan yang dapat digunakan

6. Menetapkan atau memilih kegiatan sesuai kemampuan

Tanggal : 07 Oktober 2021

Jam : $10.00-12.00$ wib

1. Melatih kegiatan sesuai kemampuan yang dipilih 1

2. Melatih kegiatan seseuai kemampuan yang dipilih 2 RTL:

Sp3

Melatih kegiatan sesuai kemampuan yang dipilih 3
O :

- Klien mampu Mengidentifikasi aspek positif yang dimiliki pasien yaitu berdoa dan bersyukur.

- Klien mampu memilih dan menetapkan kegiatan sesuai kemampuan

A : Harga Diri Rendah Situasional(+)

P :

- Berdoa,Mengikuti ibadah

- Menyapu rumah 2x/hari

\section{S : Senang}

O :

- Klien mampu melakukan kegiatan sesuai kemampuan yaitu menjahit.

- Klien mampu melatih kegiatan sesuai kemampuan yaitu menbersihkan rumah

A : Harga Diri Rendah Situasional (+) 


\begin{tabular}{|c|c|}
\hline & $\begin{array}{l}\text { P : } \\
\text { - Klien melatih kemampuan menjahit yang dimiliki } \\
\text { nya } 1 \mathrm{x} / \text { hari } \\
\text { - Berdoa,Mengikuti ibadah } \\
\text { - } \text { Mencuci piring } 2 \mathrm{x} / \mathrm{hari}\end{array}$ \\
\hline $\begin{array}{l}\text { Tanggal : } 08 \text { Oktober } 2021 \\
\text { Jam : } 14.00-16.00 \mathrm{wib} \\
\text { 1. Melatih kegiatan sesuai kemampuan yang dipilih } 3\end{array}$ & $\begin{array}{l}\text { S : Senang } \\
\text { O : Melatih kegiatan sesuai kemampuan yang dipilih } \\
\text { yaitu menyapu halaman rumah } \\
\text { A : Harga diri rendah Situasional (-) } \\
\text { P : } \\
\text { - Berdoa, Mengikuti ibadah } \\
\text { - Menyuci piring } 3 x / \text { hari } \\
\text { - Menyapu Halaman } 2 x / \text { hari } \\
\text { - Membakar sampah 1x/hari }\end{array}$ \\
\hline $\begin{array}{l}\text { Tanggal : } 06 \text { Oktober } 2021 \\
\text { Jam : } 11.00-14.00 \mathrm{wib} \\
\text { 1.Menenangkan pasien } \\
\text { 2.Memahami keadaan pasien }\end{array}$ & $\begin{array}{ll}\text { S : } & \\
\text { - } & \text { Klien mengatakan : merasa lebih tenang tetapi } \\
& \text { belum sepenuhnya cemasnya hilang } \\
\text { - } & \text { Klien mengatakan ia mampu } \\
& \text { mengindentifikasi situasi yang mencetus } \\
& \text { ansietas } \\
\mathbf{O}: & \end{array}$ \\
\hline
\end{tabular}




\begin{tabular}{|c|c|}
\hline $\begin{array}{l}\text { 3.Mendiskusikan penyebab, proses terjadinya, tanda } \\
\text { gejala,akibat } \\
\text { 4.Mengkaji tingkat ansietas } \\
\text { 5.Melatih pasien teknik relaksasi tarik nafas dalam } \\
\text { 6. Melatih pasien mengatasi ansietas dengan ditraksi dan } \\
\text { hipnotis lima jari } \\
\text { 7.Mengkaji kegiatan spritual pasien } \\
\text { 8.Mendukung keterlibatan keluarga dengan cara yang tepat }\end{array}$ & $\begin{array}{l}\text { - Klien mampu rileks dan tidak gelisah lagi } \\
\text { - Klen mampu menjelaskan kembali penjelasan } \\
\text { yang sudah diberikan } \\
\text { A : Ansietas (+) } \\
\text { P : } \\
\text { - } \quad \text { Evaluasi SP-1 dan SP-2 } \\
\text { - } \quad \text { Latihan cara mengatasi kecemasan : } \\
\text { - Teknik relaksasi napas dalam 3x/hari } \\
\text { - Distraksi : bercakap-cakap hal positif } \\
\text { - Hipnotis } 5 \text { jari fokus padahal-hal yang positif } \\
\text { 1x/hari } \\
\text {-Bantu klien melakukan latihan sesuai dengan } \\
\text { jadwal kegiatan 1x/hari }\end{array}$ \\
\hline $\begin{array}{l}\text { Tanggal : } 07 \text { Oktober } 2021 \\
\text { Jam : } 10.00 \text { wib } \\
\text { a. Latihan cara mengatasi kecemasan : } \\
\text { - Teknik relaksasi napas dalam } \\
\text { - Distraksi : bercakap-cakap hal positif } \\
\text { - Hipnotis } 5 \text { jari fokus padahal-hal yang positif } \\
\text { b. Bantu klien melakukan latihan sesuai dengan jadwal } \\
\text { kegiatan. }\end{array}$ & \begin{tabular}{|ll} 
S : & \\
- & Klien mengatakan : merasa lebih tenang dan \\
& tidak merasa cemas lagi \\
- & Klien mengatakan ia mampu \\
- & mengindentifikasi situasi yang mencetus \\
& ansietas \\
- & Klien mengatakan sudah bisa melakukan \\
& teknik tarik napas dalam \\
- & Klien mengatakan sudah bisa melakukan \\
& teknik distraksi \\
- & Klien mengatakan sudah bisa melakukan \\
& teknik hipnotis 5 jari \\
O : & \\
- & Klien mampu rileks dan tidak gelisah lagi
\end{tabular} \\
\hline
\end{tabular}




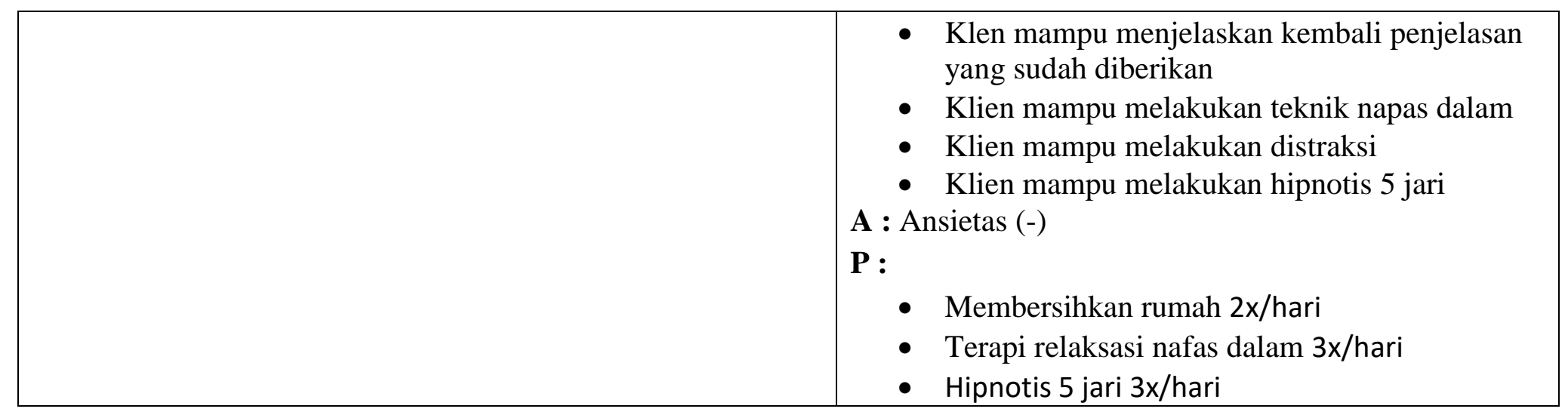




\section{BAB 4 \\ PEMBAHASAN}

Setelah penulis melaksanakan asuhan keperawatan kepada Ny. E dengan Kecemasan di Sidorame Timur maka penulis pada BAB ini akan membahasan kesenjangan antara teoritis dengan tinjauan kasus. Pembahasan dimulai melalui tahapan proses keperawatan yaitu pengkajian, diagnosa keperawatan, perencanaan, pelaksanaan dan evaluasi.

\section{A. Tahap Pengkajian}

Selama pengkajian dilakukan pengumpulan data dari beberapa sumber, yaitu dari pasien dan keluarga. Maka penulis melakukan pendekatan kepada pasien melalui komunikasi teraupetik yang lebih terbuka membantu klien untuk memecahkan perasaannya dan juga melakukan observasi kepada pasien. Adapun upaya tersebut yaitu :

a. Melakukan pendekatan dan membina hubungan saling percaya diri pada klien agar klien lebih terbuka dan lebih percaya dengan menggunakan perasaan.

b. Mengadakan pengkajian klien dengan wawancara Dalam pengkajian ini, penulis tidak menemukan kesenjangan karena ditemukan hal sama seperti: diteori: HDRS adalah suatu kegagalan dalam menjalankan fungsi dan peran yang terjadi secara tiba-tiba misalnya harus operasi, kecelakaan, dicerai suami atau istri, putus sekolah, putus hubungan kerja, perasaan malu terhadap diri sendiri karena sesuatu

\section{B. Diagnosa Keperawatan}

Diagnosis keperawatan ialah identifikasi atau penilaian terhadap pola respons klien baik actual maupun potensial dan merupakan dasar pemilihan intervensi dalam mencapai tujuan yang telah di tetapkan oleh perawat yang bertanggung jawab. Data-data yang mendukung analisa data menurut (Keliat, 2015) :

1. Harga Diri Rendah Situasional

2. Ansietas

3. Kurang Pengetahuan 


\section{A. Tahap Perencanaan}

Perencanaan dalam proses keperawatan lebih di kenal dengan asuhan keperawatan yang merupakan tahap selanjutnya setelah pengkajian dan penentuan diagnosa keperawatan. Pada tahap perencanaan mahasiswa hanya menyusun rencan tindakan keperawatan ketidak berdayaan. Pada tahap ini antara tinjauan teoritis dan tinjauan kasus tidak ada kesenjangan sehingga mahasiswa dapat melaksanakan tindakan seoptimal mungkin di dukung dengan seringnya bimbingan dengan pembimbing. Secara teoritis digunakan secara strategi pertemuan sesuai dengan diagnosa keperawatan yang muncul saat pengkajian. Adapun upaya yang digunakan mahasiswa ialah :

1. Harga diri rendah situasional

- Mengidentifikasi penyebab, tanda dan gejala, proses terjadinya dan akibat harga diri rendah situasional

- Mengidentifikasi kemampuan dan aspek positif yang dimiliki

- Menilai kemampuan yang dapat digunakan

- Menetapkan/memilih kegiatan sesuai kemampuan

- Melatih kegiatan yang sudah dipilih sesuai kemampuan

- Melakukan kegiatan yang sudah dilatih

2. Ansietas

Sp1: mendiskusikan penyebab,terjadinya prosesterjadi, tanda gejala,akibat

Sp2 :melatih teknik releksasi fisik

Sp3:melatih mengatasi ansietas dengan distraksi dan hipnotis lima

Sp4 : melatih mengatasi ansietas memalui kegiatan spiritual

3. Kurang pengetahuan

Terapi suportif, FPE

\section{B. Tahap Implementasi}

1. Harga diri rendah situasional

- Mengidentifikasi penyebab, tanda dan gejala, proses terjadinya dan akibat harga diri rendah situasional

- Mengidentifikasi kemampuan dan aspek positif yang dimiliki 
- Mendiskusikan bahwa sejumlah kemampuan dan aspek positif yang dimiliki pasien seperti kegiatan pasien dirumah, dalam keluarga dan lingkungan adanya keluarga dan lingkungan terdekat klien

- Beri pujian yang realistik/nyata dan hindarkan setiap kali bertemu dengan pasien penilian yang negatif

- Menilai kemampuan yang dapat digunakan

- Mendiskusikan pasien kemampuan yang masih dapat digunkaan saat ini

- Bantu pasien menyebutkan dan memberi penguatan terhadap kemampuan diri yang diungkapkan pasien

- Perlihatkan respon yang kondusif dan pendengar yang aktif

- Menetapkan/memilih kegiatan sesuai kemampuan

- Mendiskusikan dengan pasien beberapa kegiatan yang dapat dilakukan dan dipilih sebagai kegiatan yang akan pasien lakukan sehari-hari

- Bantu pasien menetapkan kegiatan mana yang dapat pasien lakukan secara mandiri dan minimal. Berikan contoh cara pelaksanaan kegiatan yang dapat dilakukan pasien, susun daftar kegiatan sehari-hari pasien.

- Melatih kegiatan yang sudah dipilih sesuai kemampuan

- Melatih kegiatan yang sudah dilatih

Pada diagnosa keperawatan harga diri rendah strategi pertemuan ialah mengidentifikasi masalah, mengidentifikasi aspek positif yang dimiliki, ajarkan terapi supportive, Cognitive Therapy (CT), dan family psychoedication (FPE).

\section{Tahap Evaluasi}

Pada tinjauan kasus evaluasi yang dihasilkan adalah :

1. Harga diri rendah situasional

- Klien sudah dapat mengidentifikasi penyebab, tanda dan gejala, proses terjadinya dan akibat harga diri rendah situasional 
- Klien sudah dapat melakukan kemampuan dan aspek positif yang dimiliki

- Klien sudah dapat menilai kemampuan yang dapat digunakan

- Klien sudah dapat menetapkan/memilih kegiatan sesuai kemampuan

- Klien sudah dapat melatih kegiatan yang sudah dipilih sesuai kemampuan

- Klien sudah dapat melakukan kegiatan yang sudah dilatih

2. Ansieatas

- Klien mengatakan : merasa lebih tenang dan tidak merasa cemas lagi

- Klien mengatakan ia mampu mengindentifikasi situasi yang mencetus ansietas

- Klien mengatakan sudah bisa melakukan teknik tarik napas dalam

- Klien mengatakan sudah bisa melakukan teknik distraksi

- Klien mengatakan sudah bisa melakukan teknik hipnotis 5 jari 


\section{BAB 5}

\section{PENUTUP}

\subsection{Kesimpulan}

Berdasarkan konsep asuhan keperawatan yang telah disusun dan dilaksanakan kepada Ny.E dimiliki dari pengkajian, rumusan masalah, perencanaan, pelaksanaan hingga evaluasi didapat hasil bahwa Ny.E dengan keluhan utama malu akan Penyakit Gout Artritis yang di deritanya dan malu karena menjadi tidak produktif lagi. Objektif yaitu klien tampak Badan lemas, Batuk, dan terkadang menunduk. Dari masalah masalah diatas maka diperoleh prioritas masalah yang diangkat adalah tentang Harga Diri Rendah Situasional. Kemudian diberikan intervensi secara konsep yaitu melatih kegiatan yang dipilih. Dari hasil implementasi ada beberapa intervensi yang berhasil teratasi seperti klien sudah mulai mau untuk megatakan penyakitnya yang sebenarnya, Tetapi kelien masih sedikit malu oleh rekan-rekannya yang berkerja dulu.

\subsection{Saran}

Diharapkan bagi perawat selalu berkoordinasi dengan tenaga kesehatan lainnya dalam memberikan asuhan keperawatan agar lebih maksimal terkusus pada klien dengan Harga Diri Rendah Situasional pada pasien Gout Artritis. 


\section{DAFTAR PUSTAKA}

1. Depkes. (2019). Pedoman Nasional Gout Artritis, Edisi 2. Jakarta.

2. Dwi Saptina, C. H. A. N. D. R. A. (2020). Asuhan Keperawatan Pada Klien Skizofrenia Dengan Masalah Harga Diri Rendah Kronik (Doctoral dissertation, Universitas Muhammadiyah Ponorogo).

3. Keliat, B.A., Akemat, Helena, N., \& Nurhaeni, H. (2017). Keperawatan kesehatan jiwa komunitas: CMHN (Basic course). Jakarta : EGC

4. Kemenkes RI. (2018). Riset Kesehatan Dasar, RISKESDAS.Jakarta: Kemenkes RI.

5. Kemenkes RI. (2020). Riset Kesehatan Dasar, RISKESDAS.Jakarta: Kemenkes RI.

6. Morton, L., Louise, L., Reid, H., \& Stewart, S.H. (2016). An evaluation of a CBT group for women with low self-esteem. Behavioural and Cognitive Psychotherapy. Page 221-225. First published online June 9th 2011.

7. Nies, M.A., \& McEwen, M. (2017). Community/Public Health Nursing: Promoting the Health of Populations. $4^{\text {th }}$.ed. Canada: Saunders Elsevier.

8. Novianti, G. (2019). Asuhan Keperawatan Pada Penderita Diabetes Mellitus Tipe 2 Dengan Masalah Harga Diri Rendah Situasional Di Rsud Dr. Harjono Ponorogo (Doctoral dissertation, Universitas Muhammadiyah Ponorogo).

9. Pardede, J. A., Hafizuddin, H., \& Sirait, A. (2021). Coping Strategies Related to Self-Esteem on PLWHA in Medan Plus Foundation. Jurnal Ilmu Keperawatan Jiwa, 4(2), 255-262.

10. Pardede, J. A., Hutajulu, J., \& Pasaribu, P. E. (2020). Harga Diri dengan Depresi Pasien Hiv/aids. Jurnal Media Keperawatan: Politeknik Kesehatan Makassar, 11(01).

11. Pardede, J. A., Safitra, N., \& Simanjuntak, E. Y. (2021). Konsep Diri Berhubungan Dengan Kejadian Depresi Pada Pasien Yang Menjalani Hemodialisa. Jurnal Persatuan Perawat Nasional Indonesia (JPPNI), 5(3), 92-99. http://dx.doi.org/10.32419/jppni.v5i3.240

12. Potter, P.A., \& Perry, A.G. (2015). Buku ajar fundamental keperawatan : Konsep, proses, dan praktik. Edisi 4. Jakarta: EGC.

13. Potter, P.A., \& Perry, A.G. (2019). Buku ajar fundamental keperawatan. Jakarta: Penerbit Salemba Medika. 
14. Pardede, J. A., Huda, A., Saragih, M., \& Simamora, M. (2021). Verbals Bullying Related To Self-Esteem On Adolescents. Jendela Nursing Journal (JNJ), 5(1), 1622. https://doi.org/10.31983/jnj.v5i1.6903

15. Purwanda, F., Fibriawan, Y., Sasmito, D., Fatkhunisa, \& Widiyanti, F. (2017). Tuberculosis Counter (TC) as the equipment to measure the level of TB in sputum. Indonesian Journal of tropical and infectious disease.

16. Videbeck, S.L. (2008). Buku ajar keperawatan jiwa. Jakarta: EGC.

17. Widhaswari, D. O. (2017). Asuhan Keperawatan Psikososial Harga Diri Rendah Situasional Pada Klien Dengan Diabetes Mellitus Dan Luka Gangren di Ruang Antasena RS DR. H. Marzoeki Mahdi Bogor

18. Wilkinson, J.M., \& Ahern, N. R. (2009). Buku saku diagnosis keperawatan. Edisi 9. Jakarta: EGC

19. Pardede, J. A., Simamora, M., \& Simanjuntak, G. V. (2020). Family Support and Self-Esteem of Patient with Breast Cancer. Education, 25(6), 73-5. DOI: 10.36349/EASJNM.2020.v02i03.026

20. Ramadia, A., Fadhli, R., Pardede, J. A., \& Noliwati, N. (2021, April). The Effectiveness Of Health Education Based On Health Belief Model On Knowledge Patient Pulmonary Diseases. In Al Insyirah International Scientific Conference on Health (Vol. 2, pp. 440-450). 